\title{
Recent Advancement in Synthesis of Isatin as Anticonvulsant Agents: A Review
}

\author{
Garima Mathur and Sumitra Nain* \\ Department of Pharmacy, Banasthali University, Banasthali, Rajasthan-304022, India
}

\begin{abstract}
Isatin (1H-indole-2,3-dione) and its analog, are versatile substrates which acts as a precursor for large number of pharmacologically active compounds, thus having a significant importance in the synthesis of different heterocyclic compound.Isatin shows varity of biological activities such as antimicrobial, anticancer, antiviral, anticonvulsant, antiinflammatory and analgesic. This review focused on isatin synthetic methods and its biological activity as anticonvulsant. An Isatin derivative shows potent anticonvulsant activity at low concentration among all the derivatives, Schiff bases are found to be most potent anticonvulsant agent.
\end{abstract}

Keywords: Anticonvulsant activity; Isatin; MAO -Type B; Schiff base; Structure activity relationship

\section{Introduction}

Isatin (1H-indole-2, 3-Dione) consist of indole nucleus and two types of carbonyl groups i.e. keto and lactam group. It has been discovered 150 years ago and now known as oxindole and Endogenous polyfunctional heterocyclic compounds. It was first investigated by Erdman [1] and Laurent [2] in 1841 as a product from the oxidation of indigo by nitric and chromic acids [3] (Scheme 1).

Isatin [4] and Popp [5] is used for synthesis of heterocyclic compounds [6]. In nature, isatin is found in plants of the genus Isatis [7], in Calanthe discolor LINDL [8] and in Couroupita guianensis Aubl [9]. It has also been found as a component of the secretion from the parotid gland ofBufo frogs [10], and in humans it is a metabolic derivative of adrenaline [11-13]. Substituted isatins are also found in plants, for example the melosatin alkaloids (methoxyphenylpentylisatins) obtained from the Caribbean tumorigenic plant Melochia tomentosa [14-16] as well as from fungi: 6-(3'-methylbuten- 2'-yl)isatin was isolated from Streptomyces albus [17] and 5- (3'-methylbuten-2'yl) isatin from Chaetomium globosum [18]. Isatin has also been found to be a component of coal tar [19]. Isatin has a wide varity of pharmacological activities such as antimicrobial, anticancer, antiviral, anticonvulsant, anti-inflammatory and analgesic $[6.9,11,13]$. Different research group attempted study on isatin synthetic aspect $[6,11]$. Other research group attempted study of istain biological activity [11-13]. In this review we focused on different sites of reactivity of this moiety; its structural confirmation data, different sites of action (mechanism of action) its pharmacological activity as anticonvulsants.

\section{Structural Aspects}

\section{Crystallographic data}

The crystallographic data represents that it is planar; with a large bond length of $1.55 \AA$ between the two carbonyls. The lone pair electron repulsion between the oxygen atoms $[20,21]$ was responsible for such a large bond length which was subsequently checked by comparison of bond length between cis and trans 1,2-diketones and no difference was observed [22]. A similar bond length was observed for 1-acetylisatin [23], 1-a-chloroacetylisatin [24] , diethyl (2,3-dihydro2-oxo-3- indolylidene) propanedioate [25] , 1,1'-oxalylbisisatin [26] and 1-methylisatin [27], as well as in derivatives where C-3 is tetrahedral, such as 3,3-dichloro- $1 \mathrm{H}$-indol-2(3H)-one [28] and 5'bromospiro-[1,3-dioxolano-2,3-indolin]-2'-one [29], as well as in 3-methyleneoxindoles [30] (Table 1) and in products obtained by nucleophilic ring opening of 1-acetylisatin, where the 1,2-dicarbonyl system assumes a s-trans conformation [31].

\section{Infrared spectroscopy}

The I.R. of isatin shows two strong bands at 1740 and $1620 \mathrm{~cm}-1$ corresponding to the carbonyl stretching vibrations. A broad band was found at $3190 \mathrm{~cm}-1$ due to N-H stretching, accompanied by some subbands, representing $\mathrm{N}-\mathrm{H}$ in-plane bending [32-34]. The $v \mathrm{C}=\mathrm{O}$ values modified by $\mathrm{N}$-alkylation, but $\mathrm{N}$-acetylation leads to a hypsochromic shift of the lactam absorption by $50-70 \mathrm{~cm}-1$, and the ketone band shifts to $1750 \mathrm{~cm}-1$, as a result of conjugation between nitrogen lone pair and acetyl group [35].

\section{H NMR spectroscopy}

The $1 \mathrm{H}$ NMR spectrum of isatin show the signals of the aromatic

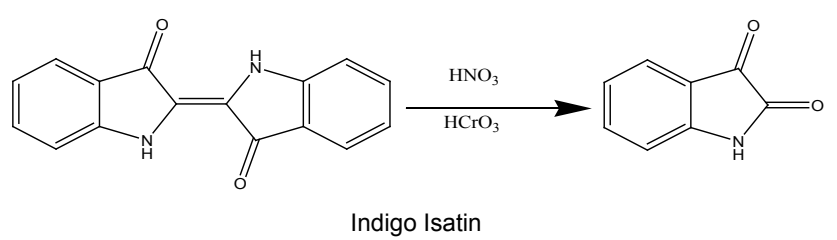

Scheme 1: Oxidation of indigo by nitric and chromic acids.

\begin{tabular}{|c|c|c|c|}
\hline $\mathrm{X}$ & $\mathrm{R} 1$ & $\mathrm{R} 2$ & $\mathrm{C}_{2}-\mathrm{C}_{3}$ \\
\hline $\mathrm{O}$ & $\mathrm{H}$ & $\mathrm{H}$ & 1.55 \\
\hline $\mathrm{O}$ & $\mathrm{Ac}$ & $\mathrm{H}$ & 1.538 \\
\hline $\mathrm{O}$ & $\mathrm{Me}$ & $\mathrm{H}$ & 1.545 \\
\hline $\mathrm{Cl}, \mathrm{Cl}$ & $\mathrm{H}$ & $\mathrm{H}$ & 1.556 \\
\hline $\mathrm{OCH}_{2} \mathrm{CH}_{2} \mathrm{O}$ & $\mathrm{H}$ & $\mathrm{Br}$ & 1.539 \\
\hline $\mathrm{CHCH}=\mathrm{C}\left(\mathrm{CH}_{3}\right)_{2}$ & $\mathrm{H}$ & $\mathrm{H}$ & 1.508 \\
\hline
\end{tabular}

Table 1: Bond length between $\mathrm{C} 2$ and $\mathrm{C} 3$ if $\mathrm{X}$ is changed [32].

*Corresponding author: Sumitra Nain, Department of Pharmacy, Banasthali University, Banasthali, Rajasthan-304022, India, Tel: +91-1438-228341; Extn. 348; Fax: +91-1438-228365; E-mail: nainsumitra@gmail.com

Received February 07, 2014; Accepted April 10, 2014; Published April 12, 2014

Citation: Mathur G, Nain S (2014) Recent Advancement in Synthesis of Isatin as Anticonvulsant Agents: A Review. Med chem 4: 417-427. doi:10.4172/21610444.1000173

Copyright: @ 2014 Mathur G, et al. This is an open-access article distributed under the terms of the Creative Commons Attribution License, which permits unrestricted use, distribution, and reproduction in any medium, provided the original author and source are credited. 
nucleus signals at 6.86 (doublet), 7.00 (triplet), 7.47 (doublet) and 7.53 (triplet) ppm (DMSO-d6), corresponding to H-7, H-5, H-4 and $\mathrm{H}-6$ respectively. $\mathrm{N}$-alkylation does not affect this pattern, whereas $\mathrm{N}$ - acetylation leads to a downfield shift of all the signals, but most significantly of H-7 due to the carbonyl group having anisotropic effect. In the same way, 3-methyleneoxindoles bearing cyano groups represents downfield shift of $\mathrm{H}-4$ by about 0.6-1.0 ppm [36,37] (Table 2).

\section{Mass spectrometry}

The electron-impact mass spectra of isatin [38], 1-alkylisatins [39] and its derivatives, such as hydrazones [40], show an intense molecular ion peak. In case of 3, 3-disubstituted oxindoles [41], the base peak represents the loss of the substituent at C-3. A peak corresponding to the loss of $\mathrm{CO}$ (ion a) can be observed, but its intensity can be decreased with the increase in size of the alkyl chain of 1-alkylisatins [42]. Ion usually loses $\mathrm{HCN}$, leading to a fulvene ion (ion b). An arene aziridine is also observed (ion c), which arises from a second loss of CO [43-45]. The ions $b$ and $c$ are also observed in the gas-phase pyrolysis of isatin [46]. In a general manner, the mass spectra of 3-substituted isatins show a sequential loss of neutral molecule [47] (Scheme 2).
A peak corresponding to the loss of $\mathrm{CO}$ is not found in the mass spectra of isatin-3-oximes, this is attributed to a Beckmann rearrangement of the molecular ion leading to a heterocyclic ring opened ion [48]. In the case of the acetylated derivatives, the molecular ion is usually of low intensity. The fragmentation pattern includes loss of ketene (ion d) and of CO (ion e) (Scheme 3).

\section{Synthetic Methods}

\section{Methods}

1. Then Sand meyerisatin synthesis [49]: Synthesis of isatin. was carried out by reaction of aniline with chloral hydrate and hydroxylamine hydrochloride in aqueous sodium sulfate leads to formation of an isonitrosoacetanilide, which is isolated on treatment with concentrated sulfuric acid to obtain isatin of $>75 \%$ overall yield [49] (Scheme 4).

2. The Stolleisatin synthesis [50]: Anilines are reacted with oxalyl chloride to form an intermediate named chlorooxalylanilide which is then cyclized in the presence of a Lewis acid, usually $\mathrm{BF}_{3} \cdot \mathrm{Et}_{2} \mathrm{O}$ or aluminum chloride, although $\mathrm{TiCl}_{4}$ has also been used in this method [50] (Scheme 5).

\begin{tabular}{|c|c|c|c|c|c|c|c|}
\hline$x$ & $\mathrm{R}$ & $\mathrm{H}-4$ & $\mathrm{H}-5$ & $\mathrm{H}-6$ & $\mathrm{H}-7$ & $\mathrm{CH}_{3} \mathrm{CO}$ & Solvent \\
\hline $\mathrm{O}$ & $\mathrm{H}$ & $7.50 \mathrm{~d}$ & $7.07 t$ & $7.60 \mathrm{t}$ & $6.92 d$ & - & DMSO-d6 \\
\hline $\mathrm{O}$ & $\mathrm{Me}$ & $7.59 d$ & $7.12 \mathrm{t}$ & $7.61 \mathrm{t}$ & $6.91 \mathrm{t}$ & - & DMSO-d6 \\
\hline O & $A c$ & $7.27 \mathrm{~d}$ & $7.33 t$ & $7.70 \mathrm{t}$ & $8.38 d$ & $2.73 \mathrm{~s}$ & DMSO-d6 \\
\hline $\mathrm{C}(\mathrm{CN})_{2}$ & $\mathrm{H}$ & $7.87 d$ & $7.12 \mathrm{t}$ & $7.59 t$ & $6.94 d$ & - & DMSO-d6 \\
\hline
\end{tabular}

Table 2: NMR data of isatin is presented [32].

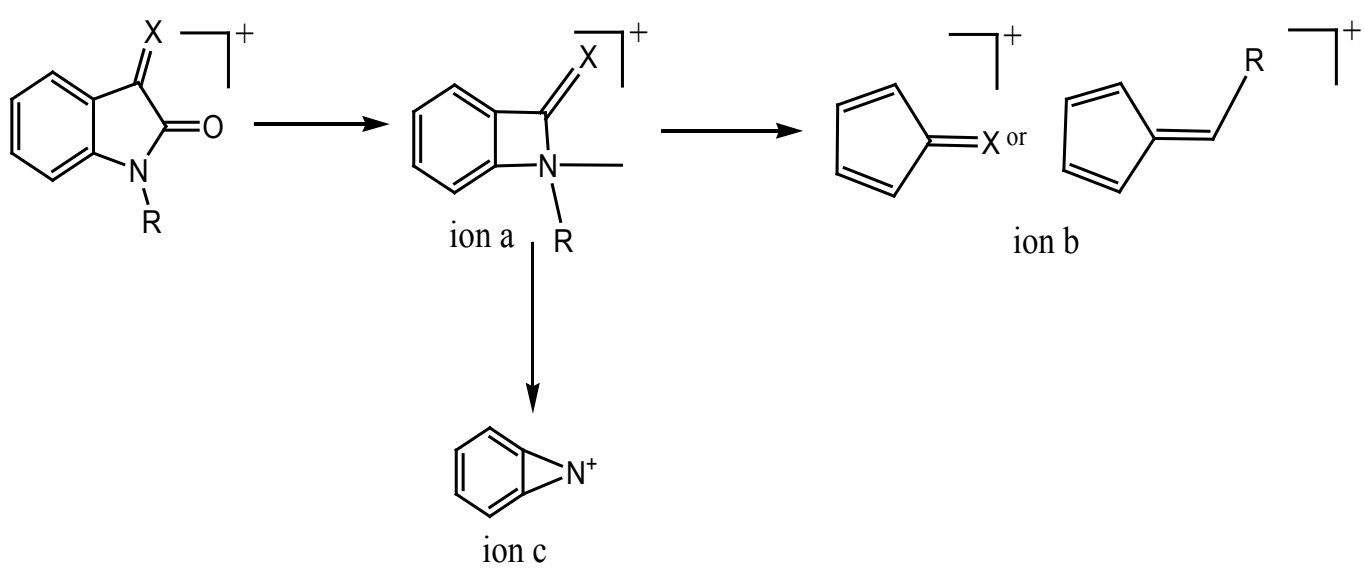

Scheme 2: Mass spectra of 3-substituted isatins show a sequential loss of neutral molecule.

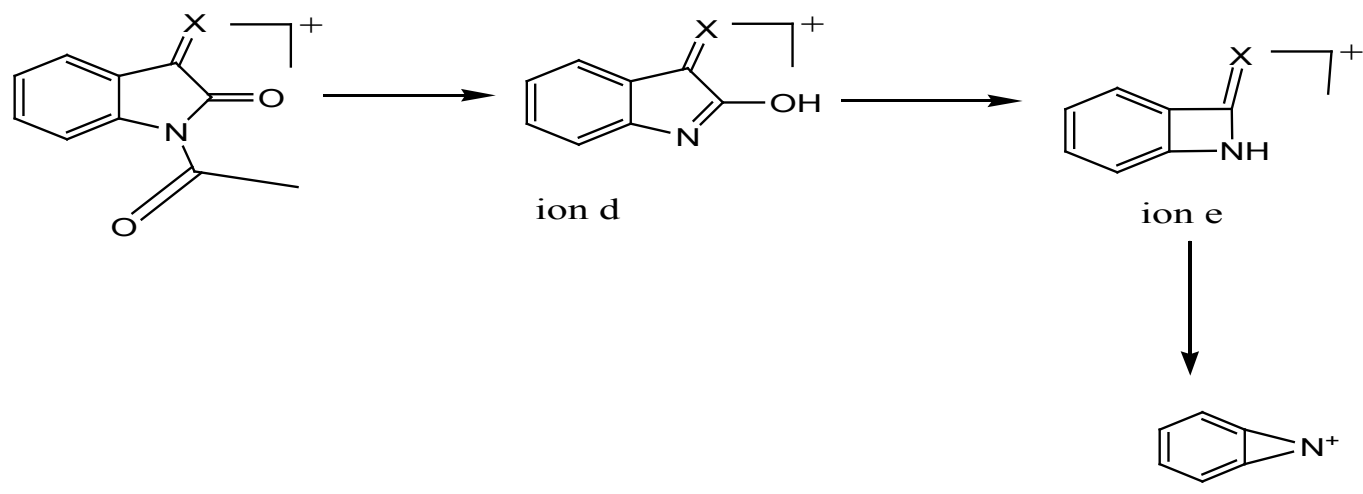

Scheme 3: Fragmentation pattern includes loss of ketene (ion d) and of $\mathrm{CO}$ (ion e). 
Citation: Mathur G, Nain S (2014) Recent Advancement in Synthesis of Isatin as Anticonvulsant Agents: A Review. Med chem 4: 417-427. doi:10.4172/2161-0444.1000173

3. The Martinet isatin synthesis [51]: Isatin was synthesized by the reaction of an amino aromatic compound with an oxomalonate ester or its hydrate in the presence of an acid to form a 3-(3-hydroxy-2-oxindole) carboxylic acid derivative which on further oxidative decarboxylation yields isatin [51] (Scheme 6).

4. The Gassman isatin synthesis [52]: This methodleads to formation of substituted isatin( $40-81 \%$ yield)by the formation and subsequent oxidation of an intermediate 3- methylthio-2oxindole [52] (Scheme 7).

5. Metalation of anilide isatin synthesis [53]: The recent method for synthesis of isatin is based on ortho-metalation (DoM) of N-pivaloyl- and N-(t-butoxycarbonyl)-anilines. The

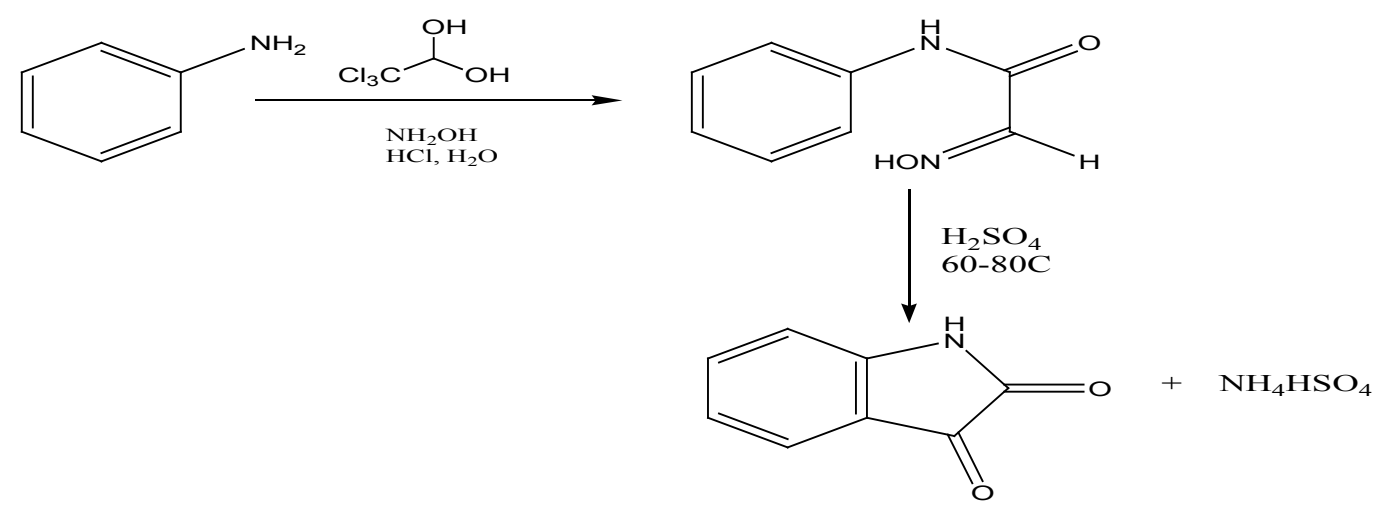

Scheme 4: Sand meyerisatin syntheses [49].<smiles>COc1cccc(OC)c1NC(=O)C(C)(C)C(=O)Oc1ccc2c(c1OC)NC(=O)C2=O</smiles>

Scheme 5: Stolleisatin syntheses [50].

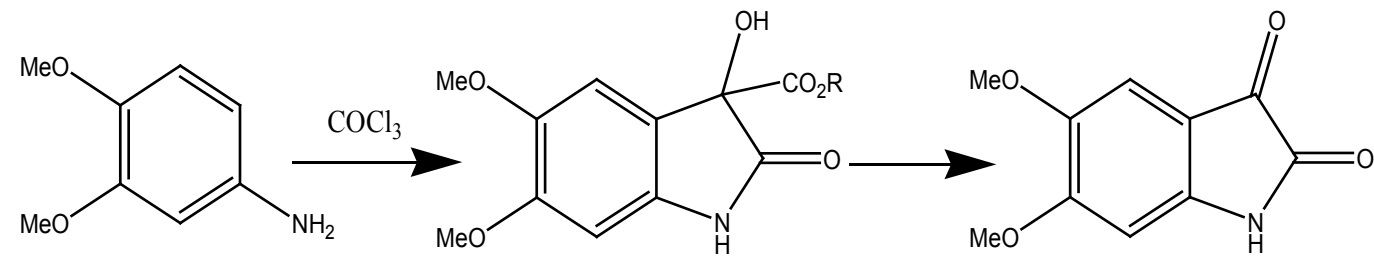

Scheme 6: Martinet isatinsyntheses [51].

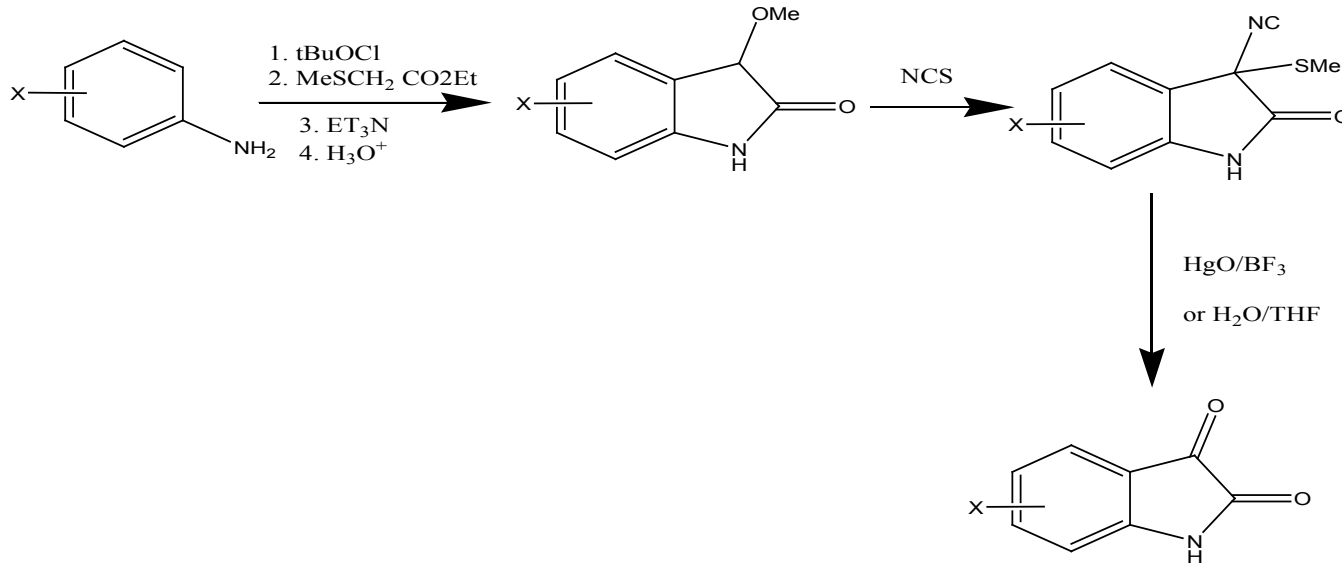

Scheme 7: Gassman isatin syntheses [52] 
dianions are treated with diethyl oxalate and then isatins are obtained after deprotection and cyclisation of the intermediate a-ketoesters. The advantage of this method is being regioselective for the synthesis of 4 -substituted isatins from meta-substituted anilines [53] (Scheme 8).

\section{Structure activity relationship}

Natasarito vaska et al. proposed that if R1 is substituted by halo groups (electron donating) than more active compound is obtained [54]. Thomson et al. proposed that Substitution at 5, 6, and 7 improves the CNS activity [55]. Nitration at C5 enhanced the anticancer activity by a factor of 4 , while the addition of a methoxy group mildly increases the cytotoxicity. Furthermore, halogenation yielded the most active compounds, with 5-bromo-, 5-iodo-, and 5-fluoroisatin being 5-10 times more active than the unsubstituted parent compound [56] (Figure 1). N- Alkylation and acylation can be done on position 1st. If substituted phenyl ring is substituted at 3 rd position than it enhances antimicrobial activity [55]. Thomson et al. proposed that a little variation at $3 \mathrm{rd}$ position may produce different degree of biological activity [55]. Prakash et al. suggested thatformation of Schiff base on reaction with aromatic amine leads to formation of compound with anticonvulsant activity [57].

\section{Chemical reactivity of isatin}

N-Alkylation: $\mathrm{N}$-alkylation of isatins was discovered by different methods, among which they are commonly alkylated by allowing isatin sodium salt to react with alkyl halides or sulphates [58,59]. Isatin sodium salt was prepared by reaction of isatin with sodium hydride, using DMF [60] or toluene under reflux [61]. Some other methods use potassium carbonate in DMF [62,63] or in acetone [64] for salt formation of isatin. The use of $\mathrm{CaH}_{2}$ in DMF was also reported [65] and this method was proposed to be used for the synthesis of both mono and bis- $\mathrm{N}$-alkylisatins. The $\mathrm{N}$-substituted isatin derivatives were also synthesized by reactions between isatin and halohydrocarbon, these reactions carried out in the presence of $\mathrm{NaOEt}$ using EtOH as solvent or in the presence of $\mathrm{NaH}$ using DMF as solvent [66]. N-Alkyl substituted isatin derivatives are known to have anticancer activity [67-69]. In 2003, N-alkyl isatin was found to induce apoptosis in human cancer cell lines, but not in normal cells [67]. Vine et al. [70] synthesised a series of di-brominated $\mathrm{N}$-substituted isatins which shows the increased potency of the halogenated isatins and also revealed that $\mathrm{N}$-methylation enhance the cytotoxicity of the parent compound [56]. In 2008 [71] different reaction conditions for $\mathrm{N}$ - alkylation of isatin were proposed using ethyl chloroacetate as alkylating agent. $\mathrm{Na}_{2} \mathrm{CO}_{3}$, $\mathrm{K}_{2} \mathrm{CO}_{3}, \mathrm{Cs}_{2} \mathrm{CO}_{3}, \mathrm{CaH}_{2}, \mathrm{TEA}, \mathrm{LiOH}, \mathrm{NMM}$, NaOEt were used as bases and DMF, DMA, HMPT, MeCN, DMSO and NMP were used as polar aprotic solvents. The best results were obtained by the use of $\mathrm{K}_{2} \mathrm{CO}_{3}$ or $\mathrm{Cs}_{2} \mathrm{CO}_{3}$ and a few drops of DMF or NMP.Other than this microwave method for synthesis of $\mathrm{N}$-alkylated [71]. Isatin was also discovered in this method an equimolar quantity of isatin and halohydrocarbon was taken to which $\mathrm{K}_{2} \mathrm{CO} 3$ as catalyst was added and DMF is used as solvent, and then exposed to microwave radiations [71]. In $2011 \mathrm{~N}$-substituted isatin was synthesized and characterized to have antioxidant activity [57].

N-Arylation: N-Arylisatin could synthesized from isatin in quantitative yields by reaction with $\mathrm{Ph}_{3} \mathrm{Bi}(\mathrm{OAc})_{2}$ andCuO under an inert atmosphere [72] or from aryl bromides and cupric oxide [73].

N-Acylation: N-Acylisatins were synthesized by different methods i.e. by using Acyl chlorides or anhydrides under reflux, either alone [74] or using perchloric acid in benzene, triethylamine in benzene [35], pyridine in benzene [75], or triethylamine in chloroform [76,77] as catalysts; or it can also be obtained by conversion of isatin to sodium isatide using $\mathrm{NaH}$ in toluene under reflux and reaction with acyl chlorides [63]. The use of diacyl chlorides, such as oxalyl chloride [78], octanedioyl or nonanedioyl chlorides [79], leads to formation of a bis-acylisatins. 2, 2-dimethylmalonyl chloride used to obtain 2, 2-dimethylmalonyl-bis-isatin was failed, and led to form an unusual

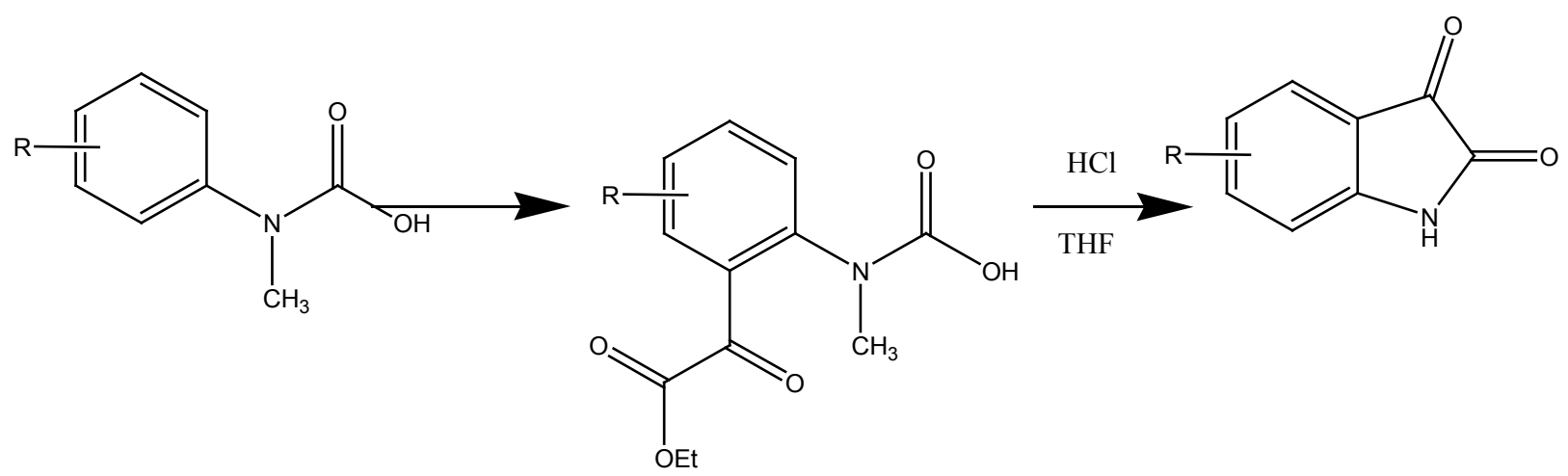

Scheme 8: Metalation of anilideisatin synthesis [53].<smiles>[R]c1ccc2c(c1)C(=O)C(=O)N2</smiles>

Figure 1: Isatin. 
tricyclic compound which was characterized by spectroscopic methods and by X-ray diffraction [26] (Scheme 9).

N-Sulfonylation: The reaction of isatin and sulfonyl chlorides helps to synthesize N-Sulfonylisatin by applying the same methodologies as used forsynthesis of 1-acylisatins. For example, 1- tosylisatin was formed in $71-74 \%$ yield by mixing tosyl chloride with isatin in presence of $\mathrm{Et}_{3} \mathrm{~N}$ or with the sodium salt of isatin [80].

N-Haloderivatives: The treatment of isatin with sodium hypochlorite in acetic acid leads to 1-chloroisatin, an effective mild oxidizing agent for the conversion of alcohols to aldehydes and ketones [81] and of indoles to 3-chloroindoles without formation of byproducts [82]. $\mathrm{N}$-[phenyliodine(III)] bisisatin can be obtained from the sodium salt of isatin and phenyliodine (III) bistrifluoroacetate in $85 \%$ yield. This compound is a member of a group of iodine (III) imides, which possess mild oxidizing properties [83].

Reactivity: The isatin with substituent attached to the aromatic ring are usually obtained from functionalized anilines, it can be synthesized by electrophilic aromatic substitution. Nitration of isatin using the sulfonitric mixture yields 5-nitroisatin [84]. The bromination of isatin in an acid catalyzed reaction gives 5, 7-dibromo-3, 3-dialkoxyoxindoles using alcohol as solvent [85]. Micro scale mono-brominationis achieved at position 5 by using $\mathrm{N}$-bromoacetamide in acetic acid medium [86] Palladium-catalyzed Suzuki cross-coupling reaction [87] facilitate arylation by the use of aryl or heteroary lboronic acids led to formation of 5-Bromoisatins 4, 6-dibromoisatin, a key intermediate in the synthesis was prepared by bromination in ethanol of a 5 -aminoisatin derivative [88] (Scheme 10).

Substitution of fluorine group at 5 th position was found to increase the biological activity. For example, Vine et al. reported an in vitro cytotoxicity for a range of mono-substituted isatins on a human monocyte-like, histiocytic lymphoma cell line [70]. Structure activity relationship (SAR) studies revealed that substitution at position 5 was favored over positions 4, 6 or 7, leading to greater cancer cell killing ability. By increasing the number of electron-withdrawing groups on the ring such as dibromo-, tribromo-, iodo- and nitro substitution on isatin led to enhance the overall biological activity against the human cancer cell lines up to 100-fold from that of the parent molecule [88]. Banerji et al. proposed microwave method for substitution at C-3 position by diamines was discovered which leads to formation of imesatins [89]. Sourabh Bhardwaj et al. suggested antimicrobial activity of Schiff bases of isatin and isatin derivatives. This procedure was modified for the synthesis of title compounds offers reduction in the reaction time, operation simplicity and easy work-up [90]. I.-J. Kang et al. proposed that isatin on $3 \mathrm{rd}$ position when substituted with thiosemicarbazonesis found to be as potent herpes simplex virus inhibitors. Thiourea moiety of thiosemicarbazone was found to be potent antiviral agent [91]. Gangarapu et al. discovered a microwave assisted substitution at 3rd position of isatin by Thiocarbohydrazide. These New Isatin Derivatives arealso known as Monothiocarbohydrazones which are Cytotoxic and Chemopreventive Agents [92].<smiles>O=C1[NH+]c2ccccc2C1=O</smiles>

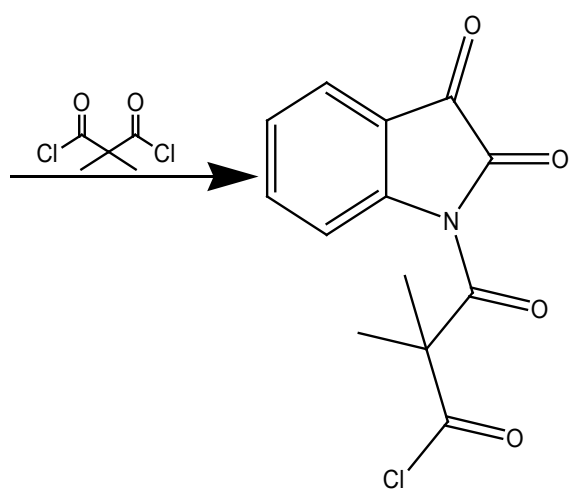

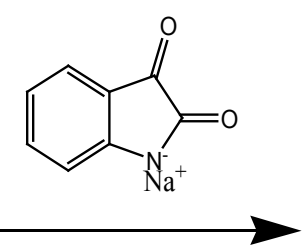

Scheme 9: Formation of a bis-acylisatins.

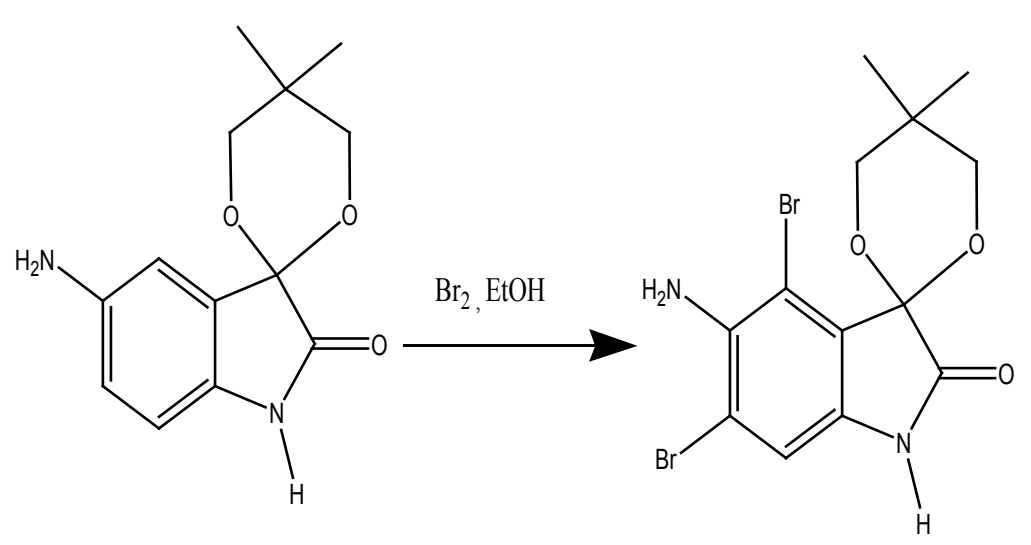<smiles>O=C1Nc2cc(Br)cc(Br)c2C1=O</smiles>

Scheme 10: 5, 7-dibromo-3, 3-dialkoxyoxindoles. 


\section{Biological Aspects}

\section{Mechanism of action: isatin}

Isatin was identified as major constituent of tribulin, it is a lowmolecular-weight inhibitor of Monoamine Oxidase Type-B (MAO-B) [93]. If urinary concentration of isatin is increased in patients it is considered as the diagnostic marker of Parkinson's disease and severity of the disease. Isatin plays an important role in the regulation of acetylcholine (Ach) in brain by increasing the level of Dopamine (DA) under stress [94,95]. Tribulin contains metabolites of isatin [96], but physiological and pathological roles of isatin and tribulin are yet not clear. Due to exercise [97] and old age [98] tribulin levels are found to be increased in humans. Tribulin excretion in human is found to be higher in females than males [99]. Tribulin appears to be enhanced in different conditions such as stress, agitation, or anxiety. Thus these observations represents that during the stress, activated catecholaminesynthesizing cells and corticotropin- releasing factor cells involved in isatin production [100] plays central roles in stress responses. Tribulin acts on central benzodiazepine receptors, and hence suggested to be an anxiety-promoting agent [101]. The potency of tribulin as mono amino oxidase (MAO inhibitory) and benzodiazepine-receptor-binding inhibitors isfound to be roughly equal [102]. It is found to be a selective MAO-B inhibitor. At much higher concentrations, it may also inhibit other enzymes, such as alkaline phosphatase [103]. Tribulin is obtained by extraction from the tissue and body fluids with ethyl acetate. It has been suggested that dietary tryptophan can be converted into an indole by the gut flora and then transported to the liver where it is oxidized. Kumar et al. (1988) [104] suggested that isatin inhibits acetylcholine esterase (AChE) activity in rat brain. The physiological role of isatin is to regulate acetylcholine (ACh) levels in the rat brain, the levels of $\mathrm{ACh}$, choline (Ch), and DA in rat tissues after $2 \mathrm{~h}$ of administration (50 or $200 \mathrm{mg} / \mathrm{kg}$, i.p.) was further elucidated, according to it $\mathrm{ACh}$ and $\mathrm{Ch}$ levels in the striatum receiving isatin increased significantly [104]. In other words, at a single dose isatin simultaneously increased the ACh and DA levels in the WKY striatum. In vitro study suggests that, isatin induced an approximate $93 \%$ inhibition of MAO and a 5\% inhibition of AChE in the rat brain which can be concluded as isatin has a higher affinity for MAO than AChE. Isatin administration also increased Ch, an $\mathrm{AChE}$ metabolite of $\mathrm{ACh}$, in many brain regions. These results suggested that isatin increased ACh levels not by inhibiting AChE activity but rather by affecting another pathway [105]. It affects the central nervous system. Isatin has been shown to inhibit a number of enzymes in various tissues, such as acid phosphatase [106], alkaline phosphatase, and xanthine oxidase, hyaluronidase [107] as well as MAO. In a variety of tests isatin are found to have antiseizure activity [108], it also enhances the antiseizure action of propranolol [109]; and its physiological effects protect against stress and certain infections. Yuwiler [110] also found that isatin can acts as benzodiazepine blocker. The most potent action of isatin is the inhibition of the atrial natriuretic peptide (ANP) binding to its receptor. Isatin attenuates ANP-stimulated guanylatecyclase activity in the rat brain, heart, and kidney [110]. Recently it was also suggested that the anxiogenic effect of isatin can be explained by its antagonism of ANP. Isatin and derivatives display diverse pharmacological activities. The biological and pharmacological properties of isatin and its derivatives have led to extensive use of these compounds as key intermediates in organic synthesis. Literature surveys reveal that various derivatives of isatin possess diverse activities such as antioxidant and anti-inflammatory [111], antimicrobial [112], antituberculosis [113], anticancer [114], anti-HIV [115], antiviral [116], anticonvulsant $[117,118]$ activities. Isatin is a core constituent of many alkaloids and drugs as well as dyes, pesticides and analytical reagents. Among all these activities anticonvulsant activity of isatin is discussed below briefly:

\section{Anticonvulsant activity}

Kumar et al. [119] found that a little variation at para position of the phenyl ring having chloro and nitro substituted compounds (Figure 2) i.e. $2 a$ and 2 brespectively have excellentanticonvulsant activity compared to that of the substitution at any otherposition. Among the synthesized compounds such as (1b) 3, 4-dihydro-2-(4-nitro phenyl) imidazo $(4,5,6)$, indol and (1c) 2-(4-chloro phenyl) -3, 4-dihydroimidazo $(4,5,6)$ indole showed excellent anticonvulsant activity.

Prakash et al. [120] reported (Figure 3) Synthesis, characterization and anticonvulsant activity of novel schiff base of isatin derivatives. They are synthesized by condensation of imesatin with different aromatic aldehydes. All the synthesized compounds screened foranticonvulsant activities against maximal electroshock (MES) and subcutaneous metrazole (ScMet).Among all the synthesized compounds, 3-(4-(3,4,5trimethoxy benzylideneamino) phenylimino) indoline-2-one showed excellentanticonvulsant activity with lower dose in MES as well as in ScMet methods.

Veerasamy et al. [121] reported the Synthesis of 3-cycloalkanone-3,

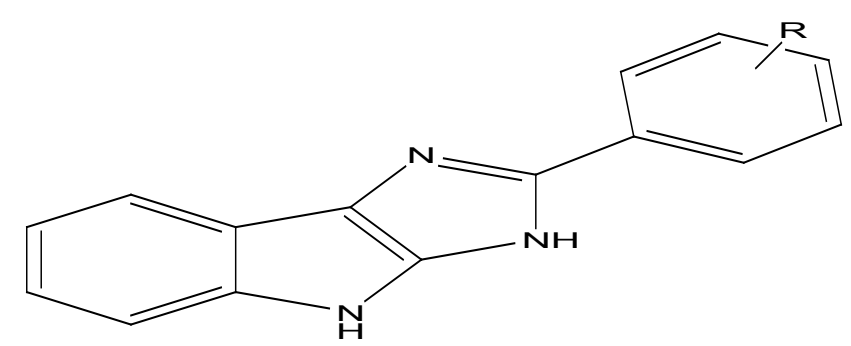

Figure 2: Phenyl indoloimidazolederivatives [119]. (2a = 4-nitrophenyl; $2 b=$ 4-chlorophenyl).

$\mathrm{R}$

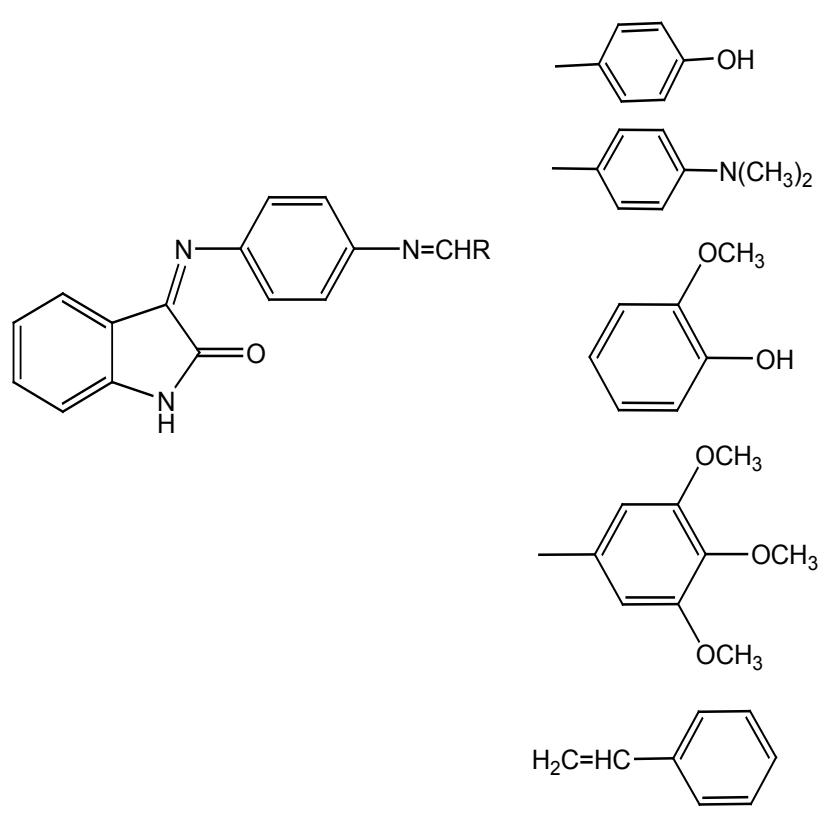

Figure 3: A series of novel Schiff base of isatin derivatives [120]. 
4-hydroxy-2-oxindolesderivatives where $\mathrm{X}$ can be bromo or chloro. These derivatives showed the MES testand PTZ test. Compound 24a was active in PTZ seizurethreshold test (PTZ), thus act as a potential anticonvulsant (Figure 4).

Subudhi et al. [122] reported anticonvulsant and antimicrobial activity of $\mathrm{Cu}$ (II), $\mathrm{Zn}$ (II) and Co (II) complex of isatin 3-Glycine.Isatin and glycine have inhibitory effects on central nervous system and to capitalize these features metal complexes of isatin-3-glycine were prepared and evaluated for anticonvulsant activity. Among them $\mathrm{Cu}$ (II) complex were found to be most active (Figure 5).

Ragavendran et al. [123] reported the synthesis of $N$-aryl/ alkylidene-4-(1, 3-dioxo-1, 3-dihydro- $2 \mathrm{H}$ isoindol-2-yl) butanoylhydrazides/butanamides which was further analyzed for anticonvulsant activity. Compounds were ineffective in MES test up to $300 \mathrm{mg} / \mathrm{kg}$. These compounds were found to be more potent when compared to standard drug phenytoin and ethosuximide, and were effective at dose $30 \mathrm{mg} / \mathrm{kg}$ (Figure 6).

Sridhar et al. [124] reported the Synthesis of 3-(4-chlorophenylimino)-5-methyl-1, 3-dihydro-indole-2-one. The synthesized compounds were active inMES test and found to be more potentwhen compared to standard drug phenytoin and ethosuximide. Among all $23 \mathrm{~b}$ was found to be most activecompound and showed $87 \%$ protection at $100 \mathrm{mg} / \mathrm{kg}$ doselevel (Figure 7).

Palluotto et al. [125] Synthesize a series of 2-aryl-2, 5 dihydropyridazino[4, 3- b]indol-3(3H)ones (Figure 8) among them some showed potent anticonvulsant activity (Figure 8).

Campagna et al. [126] Synthesize a series of a 2-aryl -2, 5-dihydropyridazino [4, 3-b] indol-3(3H) ones (Figure 9) among all

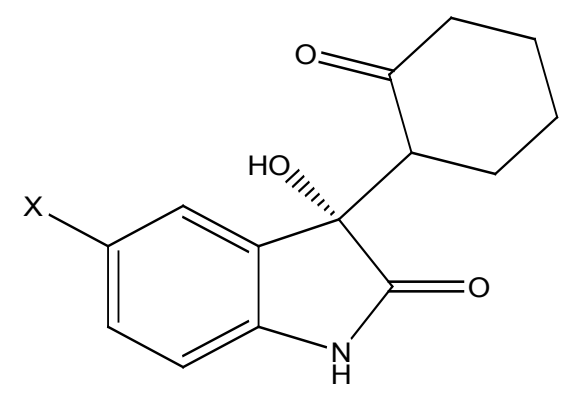

$\mathrm{X}=\mathrm{Br}, \mathrm{Cl}$

Figure 4: 3-cycloalkanone-3, 4-hydroxy-2-oxindolesderivatives [121].

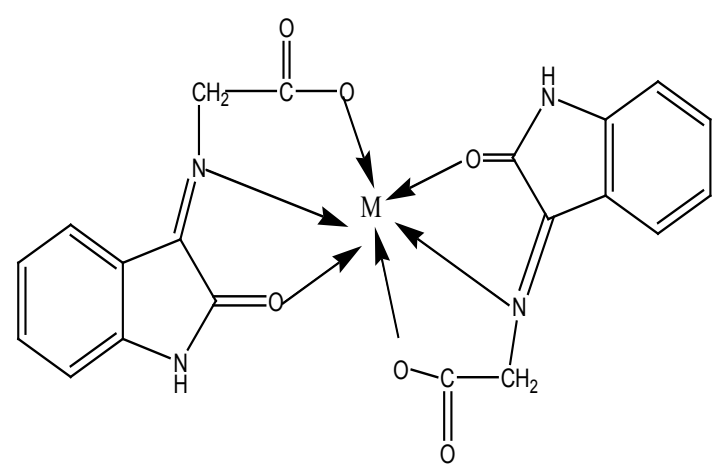

Figure 5: Metal complexes of isatin-3-glycine $(M=C u, Z n, C o)$ [122].

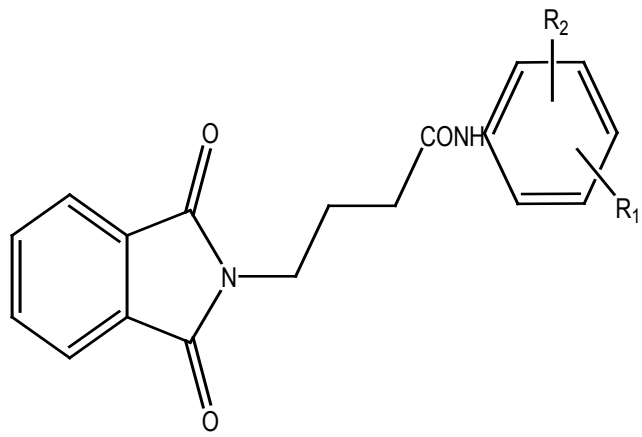

Figure 6: $\mathrm{N}$-aryl/alkylidene-4-(1, 3-dioxo-1,3-dihydro- $2 \mathrm{H}$ isoindol-2-yl) butanoylhydrazides/ butanamides $\left(\mathrm{R}_{1}=2-\mathrm{CH}_{3}, 3-\mathrm{Cl}, \mathrm{R}_{2}=4-\mathrm{CH}_{3}, 2-\mathrm{CH}_{3}\right)$ [123].

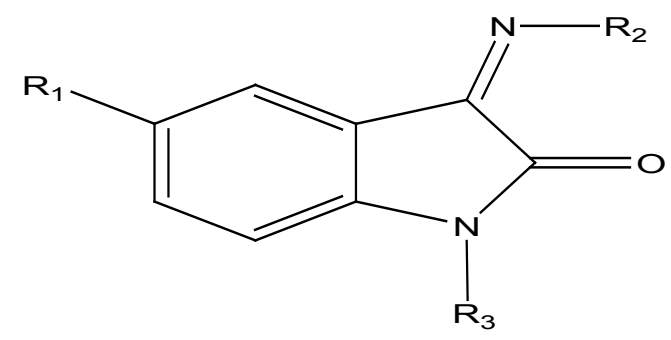

Figure 7: 3-(4-chloro-phenylimino)-5-methyl-1, 3-dihydro-indole-2-one derivative [124]. $\left(\mathrm{R}_{1}=\mathrm{H}, \mathrm{CH}_{3}, \mathrm{CH}_{3}\right.$, 4-methylphenyl, 4-chlorophenyl, 1-naphthyl, $\mathrm{R}_{3}=\mathrm{H}$ ).

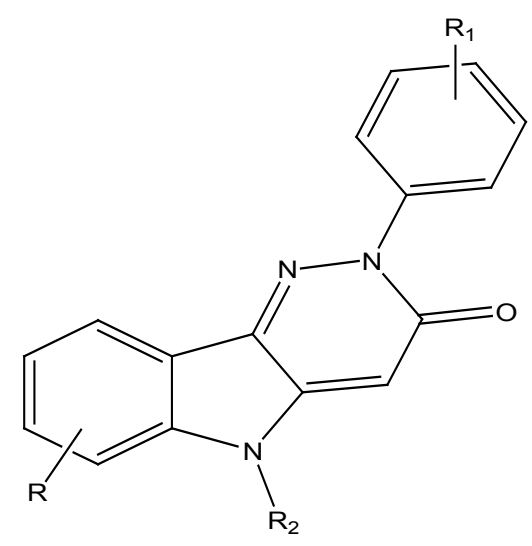

Figure 8: 2-aryl-2, 5 dihydropyridazino[4, 3- b]indol-3(3H)ones derivative [125] $\left(\mathrm{R}=\mathrm{H}, \mathrm{R}_{1}=\mathrm{p}-\mathrm{Cl}, \mathrm{p}-\mathrm{Br}, \mathrm{p}-\mathrm{OCH} 3, \mathrm{p}-\mathrm{Cl}, \mathrm{R}_{2}=\mathrm{H}, \mathrm{CH} 3\right.$ ).

compounds having $\mathrm{X}=\mathrm{H}, \mathrm{Cl}, \mathrm{Br}$ group were found to be potent against pentylenetetrazole (PTZ) and induced seizures in mice .

Popp et al. [127] studied Comparative anticonvulsant activity of different compounds (Figure 10). They found that 3-hydroxy3-acetonyloxindole (10 A) have greater anticonvulsant activity than 3-hydroxyl-3-pehenacycloindole $\left(\begin{array}{ll}10 & B\end{array}\right)$. The compounds 3-acetonyldeneoxindole (11A) and 3-acetophenylideneoxindole (11B) haveless anticonvulsant activity. Another compound 3-cyclohexenonyloxindole (11C) have enhanced activity in MES screen from 300 to $100 \mathrm{mg} / \mathrm{kg}$. Thus compound 3-hydroxy-3cyclohexanonyloxindole (10C) was found to have potent anticonvulsant drug showing activity at $300 \mathrm{mg} / \mathrm{kg}$ by body weight in the MES test.

Muller et al. [128] were found that oxindole, isatin and 
Citation: Mathur G, Nain S (2014) Recent Advancement in Synthesis of Isatin as Anticonvulsant Agents: A Review. Med chem 4: 417-427. doi:10.4172/2161-0444.1000173

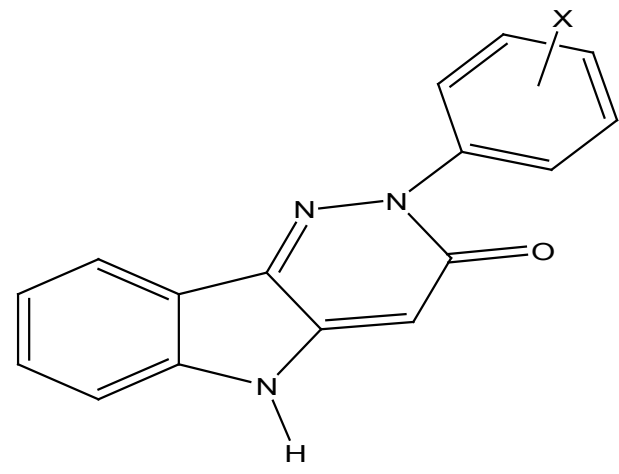

Figure 9: 2-aryl -2, 5-dihydropyridazino [4, 3-b] indol-3(3H) ones [126]. ( $\mathrm{X}=\mathrm{H}$, $\mathrm{Cl}, \mathrm{Br})$.<smiles>[R]C1(O)C(=O)Nc2ccccc21</smiles><smiles>[R]C1C(=O)N([2H])c2ccccc21</smiles>

Figure 10: Comparative anticonvulsant activity of different compounds.

NmethylIsatin-3-thiosemicarbazene injected (1/p) in the rat,inhibited monoamine oxides in liver homogenate, Isatin-3-hydrazone was much less effective as an inhibitor,introduction of Br group at the position 5 in certain analogne safforded 5-bromoisatine, 5-bromo- $\mathrm{N}$-methylisatin and 5-bromoisatin-3-hydrazone. The bromo group markedly increased the inhibitory effectiveness of the unsubstituted compounds.

\section{Applications}

Isatin is known as a colouring agent for amino acid proline, it leads to formation of a blue derivative [129]. It was used in pollens for the determination of the level of aminoacid [130-133] and other vegetal materials [134] by using paper chromatography. It has been used in a colourimetric screening test of human serum for hyperprolinemia [135], in a colourimetric assay of HIV-1 proteinase [136] and also for the estimation of the age of bones in crime investigations [137]. Isatin3-hydrazone is studied for colourimetric determination of steroids $[138,139]$. Another application of isatin is steroid analysis and it can be used as coloured marker in the Sephadex LH-20 chromatographic separation of steroidal blood components [140,141]. For the detection of amino acid by thin layer chromatography a fluorogenic derivative of isatin is reacted with tryptophan $[142,143]$. It is useful for the detection of 3,4-dehydroproline, which is oxidized by isatin and further reacted with p- dimethylaminobenzaldehydeto to give a coloured derivative [144]. 1-Chloromethylisatin has been used as a derivatizing agent for alcohols [145], small chain [146] and fatty carboxylic acids [147], and amines, including indole [148]. Isatin is also used in determination of the enzymatic activity of ketopantoyl-lactone reductase [149-151] and other fungal carbonyl reductases [152].

\section{References}

1. Otto LE (1840) Untersuchungenüber den Indigo. Journal fur Praktische Chemie 19: $321-362$.
2. Augusta L (1840) Recherchessurlindigo. Ann Chim Phys 3: 393-434.

3. Joaquim FM, Silva, Simon JG, Angelo CP (2001) The chemistry of isatin: a review. J Braz Chem Soc 12: 273-324.

4. Ward SC (1944) The Chemistry of Isatin. Chemical Reviews 34: 393-434.

5. Popp FD (1975) The Chemistry of Isatin. Adv Heterocycl Chem 18: 1.

6. Shvekhgeimer MGA (1996) Synthesis of heterocyclic compounds by the cyclization of isatin and its derivatives. Chem Heterocycl Compd (Engl Transl) 32: 249.

7. Guo Y, Chen F (1986) TLC-UV-spectrophotometric and TLC-scanning determination of isatin in leaf of Isatis. Zhongcaoyao 17: 8-11.

8. Yoshikawa M, Murakami T, Kishi A, Sakurama T, Matsuda H, et al. (1998) O-bisdesmoside, calanthoside, the precursor glycoside of tryptanthrin, indirubin, and isatin, with increasing skin blood flow promoting effects, from two Calanthe species (Orchidaceae). Chem Pharm Bull 46: 886-888.

9. Bergman J, Lindström JO, Tilstam U (1985) The Structures and Properties of Some Indolic Constituents in Courouptia Guainensis Aubl. Tetrahedron 41: 2879.

10. Wei L, Wang Q, Liu X (1982) Application of thin layer chromatography in quality control of Chinese medicinal preparation II. Qualitative analysis of some Chinese medicinal preparations of Chansu. YaowuFenxiZazhi 2: 288.

11. Ischia M, Palum MA, Prota G (1988) Adrenalin oxidation revisited. New products beyond the adrenochrome stage. Tetrahedron 44: 6441-6446

12. Palumbo A, d'Ischia M, Misuraca G, Prota G (1989) A new look at the rearrangement of adrenochrome under biomimetic conditions. Biochim Biophys Acta 990: 297-302.

13. Halket JM, Watkins PJ, Przyborowska A, Goodwin BL, Clow A, et al. (1991) Isatin (indole-2,3-dione) in urine and tissues. Detection and determination by gas chromatography-mass spectrometry. J Chromatogr 562: 279-287.

14. Kapadia GJ, Shukla BK, Chowdhury SP, Basak HM, Falesm EA (1977) Phenylpelisatins: a novel class of alkaloids from Melochiatomentosa. J Chem So Chem Commun: 535-536.

15. Kapadia GJ, Shukla YN, Basak SP, Sokoloski EA, Fales HM (1980) The melosatins a novel class of alkaloids from melochiatomentosa. Tetrahedron 36 : 2441-2447.

16. Kapadia GJ, Shukla YN (1993) Melosatin D: A New Isatin Alkaloid from Melochia tomentosa Roots. Planta Med 59: 568-569.

17. Grafe U, Radics L (1986) Isolation and structure elucidation of 6-(3'-methylbuten2 '-yl)isatin, an unusual metabolite from Streptomyces albus. J Antibiot (Tokyo) 39: 162-163.

18. Breinholt J, Demuth H, Heide M, Jensen GW, Moeller IL, et al. (1996) Prenisatin (5-(3-methyl-2-butenyl) indole-2, 3-dione): an antifungal isatin derivative from Chaetomiumglobosum. Acta Chem. Scand 50: 443.

19. Palenik GJ, Koziol AE, Katritzky AR, Fan WQJ (1990) Chem Soc Chem Commun: 715.

20. Frolova NA, Kravtsov VK, Biyushkin VN, Chumakov YM, Belkova ON (1988) Strukt Khim 29: 155.

21. Rathna A, Chandrasekhar J (1991) The influence of lone-pair repulsions on C-C bond lengths: a critical evaluation of the experimental and theoretical evidence. J Chem Soc Perkin Trans II: 1661.

22. Zukerman-Schpector J, Castellano EE, Pinto AC, Silva JFM, Barcellos MTFC (1992) Acta Cryst C48: 760.

23. Zukerman-Schpector J, Pinto AC, Silva JFM, Barcellos MTFC (1995) Acta Cryst C51: 675.

24. Zukerman-Schpector J, Pinto AC, Silva JFM, Barcellos MTFC, Pires SS, et al. (1994) Jr ActaCryst C50: 945.

25. Black DSC, Chaichit N, Gatehouse BM, Moss GI (1987) Aust J Chem 40: 1745.

26. Miehe G, Susse P, Kupcik V, Egert E, Nieger M, et al. (1991) Light absorption as well as crystal and molecular structure of $\mathrm{N}, \mathrm{N}^{\prime}$-dimethyl-indigo: An example of the use of synchrotron radiation. Angewandte Chemie International Edition in English 30: 964-967.

27. Schpector JZ, Pinto AC, Da Silva JFM, Barcellos MTFC (1993) Structure of 3,3-dichloro-1H-indol-2(3H)-one. ActaCryst C49: 173-175. 
Citation: Mathur G, Nain S (2014) Recent Advancement in Synthesis of Isatin as Anticonvulsant Agents: A Review. Med chem 4: 417-427. doi:10.4172/2161-0444.1000173

28. De A (1992) Structure of a potential anticonvulsant: 5'-bromospiro [1, 3-dioxolane-2, 3'-indolin]-2'-one. ActaCryst C48: 660-662.

29. Baba K, Kozawa M, Hata K, Ishida T, Inoue M (1981) The Structures of Yellow Pigments from the Rhizomes of Cimicifuga dahurica MAXIM. Chem Pharm Bull 29: $2182-2187$

30. Schpector JZ, Pinto AC, Da Silva JFM, Da Silva RB (1994) Structure of 2'-(N-isopropyloxamoyl)acetanilide, $\mathrm{C}_{13} \mathrm{H}_{16} \mathrm{~N}_{2} \mathrm{O}_{3}$. Acta Cryst C50: 87-88.

31. da Silva JFM, Garden SJ, Pinto AC (2001) The chemistry of isatins: a review from 1975 to 1999. J Braz Chem Soc 12: 273-324

32. Bigotto A, Galasso V (1979) Infrared and Raman spectra of phthalimide and isatin. Spectrochimica Acta Part A: Molecular Spectroscopy 35: 725-732.

33. Petrov I, Grupce O, Stafilov TJ (1986) The $\mathrm{N} \cdot \mathrm{H}$ stretching region of some imides and thioimides. Journal of Molecular Structure 142: 275-278.

34. Tomchin AB, Fradkina SP, Krylova IM, Hromenkova ZA (1986) Semicarbazone and thiosemicarbaone and heterocyclic series. XLVII. Acylation isatin. Zh. Org. Khim 22: 2409

35. Laatsch H, Thomson RH, Cox PJJ (1984) Spectroscopic properties of violacein and related compounds: crystal structure of tetramethylviolacein. J Chem Soc Perkin Trans 2 1331-1339.

36. Baron ML, Martin LL, Simmonds ID, Woolcock ML (1990) Relaxation Processes in Aromatic Methyl Groups. II. Methyl-Methyl Nuclear Overhauser Enhancements. Aust J Chem 43: 741-747.

37. Augusti R, Dias AD, Fortes ICP (1998) Utilization of a particle beam interface for the obtaintion of mass spectra of low volatile compounds in solution. Química Nova 21: 655-656.

38. Barbuch RJ, Peet NP, Coutant JE (1986) Tandem mass spectrometry study of 1-methylisatin. Organic Mass Spectrometry 21: 521-522.

39. Varma RS, Singh AP, Singh SP (1992) Electron impact mass spectra of 1-methyl-3-(2-benzothiazolylhydrazono)-2-indolinones. Organic Mass Spectrometry $27: 17-18$.

40. Zhungietu GI, Chmykhova NI, Gorgos VI, Rekhter MA, Kharinton, K.S. Khim Geterotsikl. Soedin, 1977, 642.

41. Khariton KS, Zhungietu GI, Rekhter MA, Oloi BT, Chmykhova NI (1975) Khim Geterotsikl Soedin 957.

42. Peet NP, Barbuch RJ (1984) Mass spectral fragmentation and rearrangement of isatin derivatives. Organic Mass Spectrometry 19: 171-175.

43. Zhungietu GI, Chmykhova NI, Gorgos VI, Rekhter MA, Kharinton KS et al (1977) Khim Geterotsikl Soedin 639.

44. Maquestiau A, Beugnies D, Flammang R, Freiermuth B, Wentrup C (1990) Flash-vacuum pyrolysis of 1-acylbenzotriazole: Direct observation of cyclopenta-2,4-dienylidenemethaneimines by tandem mass spectrometry and low-temperature infrared spectrometry. Organic Mass Spectrometry 25: 197 203.

45. Thétaz C, Wentrup CJ (1976) $1 \mathrm{H}$-Benzazirines. Intermediates in the ring contraction of iminocyclohexadienylidenes and arylnitrenes. J Am Chem Soc 98: 1258-1259.

46. ljaz AS, Alam M (1992) Arab J Sci Eng 17: 481.

47. Terentev PB, Mazhilis LI, Kalandarishvili AG, Stankyavichus AP (1986) Khim Geterotsikl Soedin 1052

48. Beauchard A, Laborie H, Rouillard H, Lozach O, Ferandin Y, et al. (2009) Synthesis and kinase inhibitory activity of novel substituted indigoids. Bioorg Med Chem 17: 6257-6263.

49. Loloiu G, Maior O (1997) ChemInform Abstract: Isatin Chemistry. Synthesis of N-Methyl-2, 3-dioxo-2, 3-dihydropyrrolo (2, 3-b) phenoxathiin. Chemlnform 28: 67

50. Hong Min MA, Zhan Zhu LIU, Shi Z (2003) New Approach to Synthesis of 6,7 Dimethoxyisatin. Chinese Chem Lett 14:468-470.

51. Gassman PG, Berkeley WC, Tien-Yau Luh (1977) A general method for the synthesis of isatins. J Org Chem 42: 1344-1348.

52. David SP, Johannes EM, Klein N, Alexis P, Richard JK (2007) Preparation of 3-Alkyl-Oxindoles by Copper (II)-Mediated $\mathrm{C}-\mathrm{H}, \mathrm{Ar}-\mathrm{H}$ Coupling Followed by Decarboxyalkylation. Synlett: $247-250$

53. Nataša R, Frosa A, Marina S (2013) N"-[(3Z)-1-Acetyl-5-chloro-2-oxo-1, 2-dihydro-3H-indol-3 ylidene]thiocarbonohydrazide. Molbank M: 798.
54. THOMPSON RL, PRICE ML, MINTON SA Jr (1951) Protection of mice against vaccinia virus by administration of benzaldehyde thiosemicarbazone. Proc Soc Exp Biol Med 78: 11-13.

55. Vine KL, Locke JM, Ranson M, Benkendorff K, Pyne SG, et al. (2007) In vitro cytotoxicity evaluation of some substituted isatin derivatives. Bioorg Med Chem 15: 931-938.

56. Prakash CR, Raja S, Saravanam G, Dinesh PK, Selvam TP (2011) Synthesis and Evaluation of Antioxidant Activities of Some Novel Isatin Derivatives and Analogs. Asian J Res Pharm Sci 1:140-143.

57. Arsenijevic L, Bogavac M, Pavlov S, Arsenijevic V (1985) Arh Farm 35: 39.

58. Boar BR, Cross AJ (1993) Int Appl 70.

59. Tatsugi J, Ikuma K, Izawa Y (1996) Selective photo-reduction of 1-alkylisatins in degassed alcoholic solutions. Heterocycles 43: 7-10.

60. MuchowskiJM,NelsonPH(1980)Thereactionofcarboalkoxycyclopropyltriphenylphosphonium salts with imide anions. A three step synthesis of isoretronecanol. Tetrahedron Lett 21: 4585.

61. Radul OM, Zhungietu GI, Rekhter MA, Bukhanyuk SM (1980) N-Alkylation of isatins in the presence of potassium carbonate in dimethylformamide. Khim Geterotsikl Soedin: 1562

62. Radul OM, Zhungietu GI, Rekhter MA, Bukhanyuk SM (1983) Easiest way to get 1-substituted isatins. Khim Geterotsikl Soedin 19: 353.

63. Majumdar KC, Kundu AK, Chatterjee P (1996) 1-Alkylisatins via aldol-retroaldol condensation. J Chem Res 460 .

64. Garden SJ, Torres JC, da Silva LE, Pinto AC (1998) A Convenient methodology for the N-Alkylation of isatin compounds. Synth Commun 28:1679-1689.

65. Webber SE, Tikhe J, Worland ST, Fuhrman SA, Hendrickson TF, et al. (1996) Design, synthesis, and evaluation of nonpeptidic inhibitors of human rhinovirus 3C protease. J Med Chem 39: 5072-5082.

66. Nguyen JT, Wells JA (2003) Direct activation of the apoptosis machinery as mechanism to target cancer cells. Proc Natl Acad Sci U S A 100: 7533-7538.

67. Liu Y, Lashuel HA, Choi S, Xing X, Case A, et al. (2003) Discovery of inhibitors that elucidate the role of $\mathrm{UCH}-\mathrm{L} 1$ activity in the H1299 lung cancer cell line. Chem Biol 10: 837-846.

68. Bacher G, Nickel B, Emig P, Vanhoefer U, Seeber S, Shandra A, Klenner T, Beckers TA (2001) D-24851 novel synthetic microtubule inhibitor, exerts curative antitumoral activity in vivo, shows efficacy toward multidrug-resistant tumor cells, and lacks neurotoxicity. Cancer Res 61: 392-399.

69. Vine KL, Locke JM, Ranson M, Pyne SG, Bremner JB (2007) An investigation into the cytotoxicity and mode of action of some novel $\mathrm{N}$-alkyl-substituted isatins. J Med Chem 50: 5109-5117.

70. Shmidt MS, Reverdito AM, Kremenchuzky L, Perillo IA, Blanco MM (2008) Simple and efficient microwave assisted $\mathrm{N}$-alkylation of isatin. Molecules 13 831-840.

71. Dombrowski JE, Mattingly PG (1990) Eur Pat Appl: 11.

72. Coppola GMJ (1987) N-Arylation of isatins. A direct route to $\mathrm{N}$-arylisatoic anhydrides. J Heterocyclic Chem 24: 1249-1251.

73. Pinto AC, Silva FSQ, Silva RB (1994) Reduction of $\mathrm{N}$-acylisatins with [BH3 THF] complex. Tetrahedron Lett 35: 8923-8926.

74. Black DSC, Bowyer MC, Catalano MM, Ivory AJ, Keller PA, et al. (1994) Substitution, oxidation and addition reactions at C-7 of activated indoles. Tetrahedron 50: 10497-10508.

75. Nishigashi S, Sakae M, Takamatsu S (1986) Jpn. KokaiTokkyoKoho.

76. Nishigashi S, Sakae M, Takamatsu S (1986) Jpn. KokaiTokkyoKoho 2.

77. Black DSC, Moss GI (1987) Aust J Chem 40: 129

78. Collino F, Volpe S (1982) [Mannich bases with dipiperidinic structure having pharmacological activity]. Boll Chim Farm 121: 408-420.

79. Berti C, Greci L (1981) N-Chloroisatin and 2, 2-diphenyl-2,3-dihydro-3-one1,5,7-trichloro indole: New oxidants. Synth Commun 11(9): 681

80. Berti C, Greci L, Andruzzi R, Trazza AJ (1982) New Aspects in the Chlorination of Indoles with 1 -Chlorobenzotriazole and 1-Chloroisatin. Org Chem 47: 4895 4899 
81. Papadopoulou M, Varvoglis AJ (1983) Phenyliodine (III) Bisimidates, a Novel Class of Trivalent lodine Compounds. Chem Res: 66.

82. Tomchin AB, Tumanova IV (1990) Semicarbazonesthiosemicarbazone and heterocyclic series. LV. Recycling 3-thiosemicarbazone 5 nitroizatina to form 1,2,4- triazine and indazole. Zh Org Khim 26: 1327.

83. Gasparic J, Vontor T, Lycka A, Snobl D (1990) Formation of acetals and cleavage of the five-membered ring in the bromination of isatin in alcohols. Collect Czech Chem Commun 55: 2963-2966.

84. Gopal M, Srivastava G, Pande UC, Tiwari RD (1977) Microdetermination of indoles with N-bromoacetamide in acetic acid medium. Microchim Acta 68: 215.

85. Martinez F, Naarmann $\mathrm{H}$ (1990) New isatin derivatives: synthesis and reactions. Synth Met 39: 195

86. Jnaneswara GK, Deshpande VH J (1999). Chem Res 632.

87. Vine KL, Matesic L, Locke JM, Skropeta D (2013) Advances in Anticancer Agents in Medicinal Chemistry 1: 254-312

88. Banerji J, Lai TK, Basak B, Neuman A, Prange T, Chatterjee A (2005) A novel route to anticonvulsant imesatins and an approach to cryptolepine, the alkaloid from Cryptolepis. Indian Journal of Chemistry 44B:426-429.

89. Bhardwaj S, Kumar L, Verma R, Singh UK (2010) Synthesis, characterization and antimicrobial activity of schiff bases of isatin and isatin derivatives. Journal of Pharmacy Research 3(12): 2983-2985.

90. Kang IJ, Wang LW, Hsu TA, Yueh A, Lee CC, et al. (2011) Isatin-Î' thiosemicarbazones as potent herpes simplex virus inhibitors. Bioorg Med Chem Lett 21: 1948-1952.

91. Kiran G, Maneshwar T, Rajeshwar Y, Sarangapani M (2013) MicrowaveAssisted Synthesis, Characterization, Antimicrobial and Antioxidant Activity of Some New Isatin Derivatives. Journal of Chemistry.

92. Glover V, Halket JM, Watkins PJ, Clow A, Goodwin BL, et al. (1988) Isatin: identity with the purified endogenous monoamine oxidase inhibitor tribulin. J Neurochem 51: 656-659.

93. Hamaue N, Minami M, Kanamaru Y (1992) Endogenous monoamine oxidate (MAO) inhibitor (tribulin-like activity) in the brain and urine of stroke-prone SHR. Biogen Amines 8:401-412.

94. Hamaue N, Minami M, Kanamaru Y (1994) Identification of isatin, an endogenous MAO inhibitor, in the brain of stroke-prone SHR. Biogen Amines 10: 99-110.

95. McIntyre IM, Norman TR (1990) Serotonergic effects of isatin: an endogenous MAO inhibitor related to tribulin. J Neural Transm Gen Sect 79: 35-40.

96. Armando I, Barontini M, Levin G (1984) Exercise increases endogenous urinary monoamine oxidase benzodiazepine receptor ligand inhibitory activity in normal children. J Auton Nerv Syst 1: 95-100.

97. Ueki A, Willoughby J, Glover V, Sandler M, Stibbe K, et al. (1989) Endogenous urinary monoamine oxidase inhibitor excretion in Parkinson's disease and other neurological disorders. J Neural Transm Park Dis Dement Sect 1: 263-268.

98. Clow A, Glover V, Sandler M, Tiller J (1988) Increased urinary tribulin output in generalised anxiety disorder. Psychopharmacology (Berl) 95: 378-380.

99. Tozawa Y, Ueki A, Manabe S, Matsushima K (1998) Stress-induced increase in urinary isatin excretion in rats: reversal by both dexamethasone and alphamethyl-P-tyrosine. Biochem Pharmacol 56: 1041-1046.

100.Sandler, M (1982) The emergence of tribulin. Trends Pharmacol Sci 3: 471 472.

101.Satyan KS, Rai A, Jaiswal AK, Acharya SB, Bhattacharya SK (1995) Isatin, a putative anxiogenic endocoid, induces memory dysfunction in rats. Indian J Exp Biol 33: 576-579.

102. Bansal RC, Kaur P, Kiran R (1988) Mode of interaction of isatin with rat liver alkaline phosphatase. Res Bul(Science) PU, Chandigarh 39: 71-76.

103.Kumar P, Bansal RC, Mahmood A (1993) Isatin, an inhibitor of acetylcholinesterase activity in rat brain. Biogen Amines 9: 281-289.

104. Hamaue N, Yamazaki N, Minami M (1999) Effects of isatin, an endogenous MAO inhibitor, on acetylcholine and dopamine levels in the rat striatum. Biogen Amines 5: 367-377.

105. Singh B, Sharma R, Sareen KN, Sohal MS (1977) Isatin enzyme interactions. $\mathrm{V}$. Activation of rat liver acid phosphatase. Enzyme 22: 256-261.
106. Kumar P, Dani HM, Trehan S (1977) Effect of isatin on testicular hyaluronidase. Indian J Exp Biol 15: 655-656.

107. Chocholova L, Kolinova M (1979) Effect of isatin (2,3-dioxoindoline) on audiogenic seizures in rats and its relationship to electrographic and behavioural phenomena. Physiol Bohemoslov 28: 495-502.

108. MÃ $1 / 4$ ller M, Schramek J (1989) Combined application of propranolol and local anesthetics: enhanced anticonvulsant action. Biomed Biochim Acta 48: 333336.

109. Yuwiler A (1990) The effect of isatin (tribulin) on metabolism of indoles in the rat brain and pineal: in vitro and in vivo studies. Neurochem Res 15: 95-100.

110. Glover V, Medvedev A, Sandler M (1995) Isatin is a potent endogenous antagonist of guanylate cyclase-coupled atrial natriuretic peptide receptors. Life Sci 57: 2073-2079.

111. Mohan S, Saravanan J, Singh D, Sharma PC (2007) Synthesis and evaluation of some novel piperidinothiophenes as potential antioxidant and antiinflammatory agents. Acta Pharm 49: 29-38.

112. Sridhar SK, Saravanan M, Ramesh A (2001) Synthesis and antibacterial screening of hydrazones, Schiff and Mannich bases of isatin derivatives. Eur J Med Chem 36: 615-625.

113. Tran VH, Nguyen QD, Le NV, Le TT (2000) Study on antituberculosis effect of some thiosemicarbazones and isonicotinylhydrazone derivatives of Isatin and 5-halogino Isatin. Tap Chi Douc Ho 8: 15-17.

114. Islam MR, Muhsin M (2007) Synthesis of 5-chloroisatin-6, 7-dimethylisatin and their carbohydrazone ?2-1, 3, 4-oxadiazoline and their cytotoxicity studies. Bangladesh J Pharmacol 2: 7-12.

115. Selvam $P$, Chandramohan M, De Clercq E, Witvrouw M, Pannecouque $C$ (2001) Synthesis and anti-HIV activity of 4-[(1,2-dihydro-2-oxo-3H-indol-3ylidene) amino]-N(4,6-dimethyl-2-pyrimidinyl)-benzene sulfonamide and its derivatives. Eur J Pharm Sci 14: 313-316.

116. Sin N, Venables BL, Combrink KD, Gulgeze HB, Yu KL, et al.( 2009) Respiratory, syncytial virus fusion inhibitors part 7 , structure activity relationship with a series of isatinoximes that demonstrate antiviral activity invivo. Bioorg Med ChemLett. 19: 4857- 4862.

117. Verma M, Pandeya SN, Singh KN, Stables JP (2004) Anticonvulsant activity of Schiff bases of isatin derivatives. Acta Pharm 54: 49-56.

118. Kumar N, Sharma PK, Garg VK, Singh P(2011) Synthesis and Anticonvulsant Activity of Novel Substituted Phenyl Indoloimidazole Derivatives. Current Reseach in Chemistry 3: 114-120.

119. Prakash CR, Raja S, Saravanan G IJ (2010) Pharm \& Pharmaceutical Sci 2 177-181.

120. Raj M, Veerasam N, Singh VK (2010) Highly enantioselective synthesis of 3-cycloalkanone-3- hydroxy-2-oxindoles, potential anticonvulsants. Tetrahedron Tetrah. Lett 51: 2157-2159.

121. Subudhi BB, Pandaa PK, Bhattaa D, Jenab A(2009) Anticonvulsant and Antimicrobial Activity of $\mathrm{Cu}$ (II), Zn (II) and Co (II) Complex of Isatin 3-Glycine. Iranian J. Pharm. Sci. Spring 5: 83-88.

122. Ragavendran JV, Sriram D, Patel SK, Reddy IV, Bharathwajan N, et al. (2007) Design and synthesis of anticonvulsants from a combined phthalimide-GABAanilide and hydrazone pharmacophore. Eur J Med Chem 42: 146-151.

123. Sridhar SK, Pandeya SN, Stables JP, Ramesh A (2002) Anticonvulsan activity of hydrazones, Schiff and Mannich bases of isatin derivatives. Eur Pharm Sci 16: 129-132.

124. Palluotto F, Carotti A, Casini G, Campagna F, Genchi G, et al. (1996) Structureactivity relationships of 2-aryl-2,5-dihydropyridazino [4,3-b]indol-3(3H)-ones at the benzodiazepine receptor. Bioorg Med Chem 4: 2091-2104.

125. Campagna F, Carotti A, Casini G, Palluotto F, Genchi (1993) 2-Aryl-2, 5-ihydropyridazino [4,3-b] indol-3(3-H) ones. Bioorg. Med. Chem 1: 437-446.

126.Popp FD, Donigan BE (1979) Synthesis of 3-hydroxy-3-phenacyloxindole analogs. J Pharm Sci 68: 519-520.

127. Mueller M, Schmiedel R (1965) On The Effects Of Compounds Structurally Related To Isatine (2,3-DIOXOINDOLINE) on monoamine oxidase activity of mouse liver homogenates. Acta Biol Med Ger 14: 158-166.

128. Elliott RJ, Gardner DL (1976) Proline determination with isatin, in the presence of amino acids. Anal Biochem 70: 268-273. 
Citation: Mathur G, Nain S (2014) Recent Advancement in Synthesis of Isatin as Anticonvulsant Agents: A Review. Med chem 4: 417-427. doi:10.4172/2161-0444.1000173

129. Palfi G, Palfi Z (1982) A rapid method for the determination of fertility of maize pollen with the proline-isatin reaction.

130. Palfi G, Gulyas S, Szollosi I (1987) Acta Biol 33: 25.

131. Gulyas S, Palfi G (1986) Sov Plant Physiol-Engl Tr 33: 472.

132. Kapyla, M Grana (1991) 30: 1992.

133. Eriksen $A B(1976)$ Quantitative determination of the amino acid proline by glass fiber paper chromatography. Medd Nor InstSkogforsk 32: 389.

134. Broadhurst AV, Roberts NA, Ritchie AJ, Handa BK, Kay C (1991) Assay of HIV-1 proteinase: a colorimetric method using small peptide substrates. Anal Biochem 193: 280-286.

135. Bonte W, Johansson J, Garbe G, Berg S (1976) [Determination of the amino acid spectrum as an aid in the up-dating of skeletal findings]. Arch Kriminol 158: $163-174$

136. Dochinets DI, Zorya BP, Petrenko VV, Klyuev NA, Ukr Khim Zh, et al. (1989) (Russ. Edition) 55: 389.

137. Dochinets DI, Petrenko VV, Zorya BP, Zh Anat Khim (1989) 44: 510.

138. Sybulski S, Maughan GB (1975) A rapid method for the measurement of estradiol and hydrocortisone levels in maternal and fetal blood and amniotic fluid. Am J Obstet Gynecol 121: 32-36.

139. Kachel CD, Mendelsohn FA (1979) An automated multicolumn system for chromatography of aldosterone on Sephadex LH-20 in water. J Steroid Biochem 10: 563-567.

140. Trigoso Cl, Ibanez N, Stockert JC (1993) A specific fluorogenic reaction for tryptophan residues using isatin in organic solvents. J Histochem Cytochem 41: 1557-1561.

141.Datta S, Datta SC (1979) Spray reagents for the detection of p-phenylazophenylthiohydantoins of amino acids on silica gel plates. J Chromatogr 170: 228.

142. Panikkar B, Kuttan R (1989) Detection and estimation of 3,4-dehydroproline. Indian J Biochem Biophys 26: 126-128.

143. Wendelin W, Knotz F, Schramm HW (1975) Monatsh. Chem 106: 159.

144. Gubitz G, Wendelin W (1979) Quantitative thin-layer chromatography and mass spectrometry of isatinylmethyl esters of carboxylic acids. Anal. Chem 51:1690-1693

145. Gubitz G (1980) Derivatizaton of fatty acids with 1-chlormethylisatin for highperformance liquid chromatography. J. Chromatogr. 187- 208-211

146.Zhungietu GI, Sinyavskaya LP, Filipenko TY (1977) Interaction 1 hlormetilizatina with indole. Khim. Geterotsikl. Soedin 217.

147. Kataoka M, Doi Y, Sim TS, Shimizu S, Yamada H (1992) A novel NADPHdependent carbonyl reductase of Candida macedoniensis: purification and characterization. Arch Biochem Biophys 294: 469-474.

148. Hata H, Shimizu S, Hattori S, Yamada H (1989) Ketopantoyl-lactone reductase from Candida parapsilosis: purification and characterization as a conjugated polyketone reductase. Biochim Biophys Acta 990: 175-181.

149. Julliard JH (1994) Purification and characterization of oxopantoyl lactone reductase from higher plants: role in pantothenate synthesis. Bot. Acta, 107: 191-200.

150. Shimizu S, Hattori S, Hata H, Yamada H (1988) A novel fungal enzyme, NADPH-dependent carbonyl reductase, showing high specificity to conjugated polyketones. Purification and characterization. Eur J Biochem 174: 37-44.

151. Nassenstein A, Hemberger J, Schwartz H, Kula MR (1992) Studies on the enzymatic reduction of N-Boc-4S-amino-3-oxo-5-phenylpentanoic acid methylester. J Biotechnol 26: 183-201. 